\title{
The effect of restraint stress in early pregnancy in mice
}

\author{
J. L. Wiebold, P. H. Stanfield, W. C. Becker and J. K. Hillers \\ Department of Animal Sciences, Washington State University, Pullman, Washington 99164, U.S.A.
}

\begin{abstract}
Summary. Mice were exposed to $5 \mathrm{~h}$ of restraint stress on Days 1-3, 4-6, or 1-6 of pregnancy in the morning (08:30-13:30 h, a.m.) or afternoon (13:30-18:30 h, p.m.). Stress reduced the pregnancy rate from 90 to $52 \%(P<0.005)$ and average litter size on Day 18 from $8 \cdot 2$ to $5 \cdot 2$ young $(P<0 \cdot 005)$. Stress for 6 days was more effective than for 3 days $(P<0.005)$ and an a.m. stress was more effective than a p.m. stress $(P<0.05)$ in reducing the average litter size. Animals examined on Day 7 after 6 days of a.m. stress had decreased numbers of normal corpora lutea (CL), increased numbers of abnormal $\mathrm{CL}$, decreased serum progesterone concentrations and tended to have fewer implantation sites. Abnormalities of embryo transport and implantation were also present. Changes in CL morphology and embryo transport and development were evident on Day 4 after only 3 days of restraint stress. These results show that many reproductive events of early pregnancy can be disrupted by restraint stress.
\end{abstract}

\section{Introduction}

Stress during pregnancy has adverse effects on reproductive function in laboratory rodents. Stressing animals throughout gestation or in the last third of pregnancy can result in diminished fertility, intrauterine mortality and behavioural changes in the offspring (Christian \& Lemunyan, 1958; Keeley, 1962; Herrenkohl, 1979). Few reports are available on the effects of stress or stress hormones in early pregnancy. Auditory stimuli at regular intervals for $48 \mathrm{~h}$ appeared to interfere with the implantation process in rats (Zondek \& Tamari, 1967), but the exact stage of pregnancy at the time of stimulation was not known. Administration of adrenocorticotrophic hormone (ACTH) on the day of mating and for 6 subsequent days reduced the litter size in rats and this effect appeared to be mediated through the adrenal glands (Velardo, 1957). In contrast, Kittinger, Gutierrez-Cernosek, Cernosek \& Pasley (1980) reported that ACTH treatment for the first 8 days of pregnancy reduced the number of implantation sites in intact and adrenalectomized mice. Restraint stress for $2 \mathrm{~h}$ on each of the first 5 days of pregnancy can decrease average litter size in rats (Euker \& Riegle, 1973) but no comparable studies have been reported for mice.

This paper reports the results of experiments on the effects of restraint stress in early pregnancy in mice and examines how these effects may be mediated.

\section{Materials and Methods}

Preliminary trials indicated that female mice had lower pregnancy rates when restraint stress was applied for $5 \mathrm{~h}$ on each of the first 6 days of pregnancy. Three experiments were then designed to determine the effect (1) of time of day or number of days of restraint stress on pregnancy rate and litter size; (2) of 6 days of restraint stress on reproductive characteristics on Day 7 of pregnancy; and (3) of 3 days of restraint stress on reproductive characteristics on Day 4 of pregnancy.

General. Mature mice (11-13 weeks) were produced by crossing B6D2 F1 females (Jackson Laboratories. Bar Harbor, ME) with Swiss-Webster (SW) males. All animals were kept at $21^{\circ} \mathrm{C}$ with a $14 \mathrm{~h}(06: 00-20: 00 \mathrm{~h})$ light, $10 \mathrm{~h}$ dark photoperiod. Virgin females were placed with $\mathrm{SW}$ males and checked daily for copulatory plugs. Use was made of the Whitten effect (Whitten, 1956) to obtain 
large numbers of mated females on any one day. Upon detection of a vaginal plug (Day 1), females were weighed and assigned to treatments by weight.

Restraint stress was applied by immobilizing mice in wire-mesh cones for $5 \mathrm{~h}$ daily (Blecha, Kelley \& Satterlee, 1982). Mice usually entered the cones willingly but were prevented from exiting by blocking retreat. Controls remained in their cages with food and water during the time treated females were stressed. Although stressed animals were deprived of food and water during restraint, separate experiments have shown that food and water deprivation alone for $5 \mathrm{~h}$ daily has no effect on pregnancy rate, litter size, or weight gain during the first week of pregnancy (data not shown).

Experiment 1: effect of restraint stress (time of day and number of days) on pregnancy rate and litter size. Mice were assigned to one of 6 stress treatments or as a control $(\mathrm{N}=20$ for each treatment or the control group). Restraint stress was applied at 08:30-13:30 h (a.m.) or 13:30-18:30 h (p.m.) on Days 1, 2 and 3, 3, 4 and 6, or 1-6 of pregnancy. Two replicates of 70 mice each were run. Mice were killed at Day 18 and pregnancy status and litter size were determined. Differences in pregnancy rate on Day 18 were tested by $\chi^{2}$ analysis. The model used for statistical analysis of litter size included replication, treatment and their interaction and dam weight (on Day 1) as a covariate. The tests of significance were computed assuming a fixed model. The use of a parametric analysis of variance is justified by the large number of samples and assumption of the central limit theorem. Linear contrasts were used to compare (a) control and stressed animals, (b) a.m. and p.m. stress, (c) stress for 6 or 3 days and (d) stress on Days 1-3 or Days 4-6. Values from all animals were included. A separate linear contrast was performed to compare litter size in only those control and stressed animals that were pregnant at Day 18 . Student's $t$ test was used to determine the significance of differences in Day 1 body weights for control and stressed animals that were pregnant and non-pregnant on Day 18.

Experiment 2: effect on Day 7 of 6 days of restraint stress. Mice that had vaginal plugs on the same day were paired by weight and randomly assigned to a control or restraint stress for $5 \mathrm{~h}$ a.m. on Days $1-6$ of pregnancy (12 pairs). On Day 7 of pregnancy, animals were killed. The number and size of implantation sites in the uterine horns were noted. Oviducts were flushed with BMOC-2 (Brinster, 1965) and the flushings examined with a dissecting microscope (up to $\times 70$ magnification) for embryos. Embryos recovered were classified as to stage of development. Uteri were also flushed if no implantation sites were visible and these flushings were also examined. Ovaries were dissected free of fat and the bursal membrane. The number and gross morphological appearance of the corpora lutea $(\mathrm{CL}$, red or pink $=$ normal, pale or white $=$ abnormal) were recorded. For 6 of the 12 pairs of mice, animals were killed by decapitation, trunk blood was collected, and serum stored at $-15^{\circ} \mathrm{C}$. Progesterone was measured by radioimmunoassay as described by Surve, Bacso, Brinckerhoff \& Kirsch (1976) and Chang \& Estergreen (1983). The level of sensitivity of the RIA for $10 \mu \mathrm{l}$ mouse serum was $2.5 \mathrm{ng} / \mathrm{ml}$. Extraction efficiency was $95 \%$. Intra-assay coefficient of variation was $7 \cdot 2 \%$ (all samples run in one assay). Statistical analysis was by $\chi^{2}$ or the Wilcoxon signed ranks test.

Experiment 3: effect on Day 4 of 3 days of restraint stress. Mice that had vaginal plugs on the same day were paired by weight and randomly assigned to a control or restraint stress for $5 \mathrm{~h}$ a.m. on Days 1-3 of pregnancy (10 pairs). On Day 4 of pregnancy, animals were killed. All uteri and oviducts were flushed and examined as in Exp. 2 and ovaries were also examined. Statistical analysis was by $\chi^{2}$ and the Wilcoxon signed ranks test.

\section{Results}

\section{Experiment 1}

As shown in Table 1, restraint stress for 3 or 6 days in early pregnancy reduced pregnancy rates 
Table 1. Effect of a $5 \mathrm{~h}$ stress at $08: 30-13: 30 \mathrm{~h}$ or $13: 30-18: 30 \mathrm{~h}$ on different days of pregnancy

\begin{tabular}{lcc}
\hline Days and time of stress & Pregnancy rate & Litter size ${ }^{\dagger}$ \\
\hline Control & $18 / 20^{*}$ & $8 \cdot 2 \pm 0 \cdot 8$ \\
08:30-13:30 h (a.m.) & & \\
Days 1-6 & $4 / 20$ & $2 \cdot 1 \pm 1 \cdot 0$ \\
Days 1-3 & $12 / 20$ & $5 \cdot 6 \pm 1 \cdot 2$ \\
Days 4-6 & $11 / 20$ & $5 \cdot 4 \pm 1 \cdot 2$ \\
13:30-18:30 h (p.m.) & & \\
Days 1-6 & $8 / 20$ & $4 \cdot 4 \pm 1 \cdot 3$ \\
Days 1-3 & $14 / 20$ & $7 \cdot 0 \pm 1 \cdot 1$ \\
Days 4-6 & $13 / 20$ & $6 \cdot 6 \pm 1 \cdot 1$ \\
All stressed animals & $62 / 120^{*}$ & \\
& & \\
\hline
\end{tabular}

$\dagger$ Mean \pm s.e.m., $N=20$.

$* P<0.005$.

Table 2. Linear contrasts for litter size (mean \pm s.e.m.)

\begin{tabular}{|c|c|c|c|}
\hline \multirow{2}{*}{$\begin{array}{l}\text { Contrast } \\
\text { Control } v s \text { stress }\end{array}$} & \multicolumn{2}{|c|}{ Litter size } & \multirow{2}{*}{$\begin{array}{r}\text { Significance } \\
P<0.005\end{array}$} \\
\hline & $\begin{array}{l}8 \cdot 2 \pm 0 \cdot 8 \\
(\mathrm{~N}=20)\end{array}$ & $\begin{array}{l}5 \cdot 2 \pm 0.5 \\
(\mathrm{~N}=120)\end{array}$ & \\
\hline $\begin{array}{r}08: 30-13: 30 \mathrm{~h} \text { stress } v s \\
13: 30-18: 30 \mathrm{~h} \text { stress }\end{array}$ & $\begin{array}{l}4 \cdot 4 \pm 0 \cdot 7 \\
(\mathrm{~N}=60)\end{array}$ & $\begin{array}{l}6 \cdot 0 \pm 0 \cdot 7 \\
(\mathrm{~N}=60)\end{array}$ & $P<0.05$ \\
\hline $\begin{array}{l}\text { Days } 1-6 \text { stress vs Days } \\
1-3 \text { or } 4-6 \text { stress }\end{array}$ & $\begin{array}{l}3 \cdot 3 \pm 0 \cdot 8 \\
(N=40)\end{array}$ & $\begin{array}{l}6 \cdot 1 \pm 0 \cdot 6 \\
(\mathrm{~N}=80)\end{array}$ & $P<0.005$ \\
\hline $\begin{array}{r}\text { Days } 1-3 \text { stress } v s \\
\text { Days } 4-6 \text { stress }\end{array}$ & $\begin{array}{l}6 \cdot 3 \pm 0 \cdot 8 \\
(\mathrm{~N}=40)\end{array}$ & $\begin{array}{l}6 \cdot 0 \pm 0.8 \\
(\mathrm{~N}=40)\end{array}$ & $P=0.65$ \\
\hline $\begin{array}{l}\text { Control vs stress, } \\
\text { pregnant animals only }\end{array}$ & $\begin{aligned} 9 \cdot 2 & \pm 0 \cdot 6 \\
(\mathrm{~N} & =18)\end{aligned}$ & $\begin{array}{r}10 \cdot 0 \pm 0 \cdot 3 \\
(\mathrm{~N}=62)\end{array}$ & $P=0.16$ \\
\hline
\end{tabular}

$(P<0.005)$. Neither replicate nor replicate by treatment interaction had an effect on average litter size, therefore data from the two replicates were pooled. Dam weight on Day 1 affected subsequent litter size $(P<0.0001)$ with heavier dams bearing larger litters.

Linear contrasts (Table 2) revealed that stressed animals had smaller average litter sizes than did control animals $(P<0.005)$. Animals stressed a.m. had smaller average litter sizes than did animals stressed p.m. $(P<0 \cdot 05)$. Animals stressed for 6 days had smaller average litter sizes than did animals stressed for 3 days $(P<0.005)$ but there was no difference in average litter size for animals stressed on Days 1-3 or Days 4-6 of pregnancy $(P>0 \cdot 10)$.

Control and stressed animals that were pregnant on Day 18 did not differ in litter size, although stressed animals that were pregnant on Day 18 tended to have larger litters than controls $(P=0.16)$. Control mice that were pregnant or non-pregnant on Day 18 did not differ in Day 1 body weights $(24.7 \pm 0.5$ and $24.2 \pm 1.4 \mathrm{~g}$, respectively, means \pm s.e.m., $P>0.10)$ but stressed mice that were pregnant on Day 18 had been heavier $(P<0.001)$ on Day $1(25.5 \pm 0.2 \mathrm{~g})$ than stressed mice that were not pregnant $(24 \cdot 2 \pm 0 \cdot 3 \mathrm{~g})$. 
Experiment 2

On Day 7 of pregnancy $75 \%$ of control mice and $50 \%$ of stressed mice had implantation sites. The average numbers of implantation sites tended to be different $(P<0 \cdot 10)$ for control and stressed mice (Table 3). In one of the stressed mice, however, all 9 implantation sites were small and appeared to be undergoing resorption. Two control mice and one stressed mouse had 1-3 unfertilized eggs in the oviducts (one of these two controls also had 9 normal implantation sites). One stressed mouse had 7 degenerate embryos in the oviducts and no implantation sites. One stressed mouse that had no implantation sites did have 3 hatched blastocysts flushed from the uterus. (Hatching refers to escape of the embryo from the zona pellucida or the dissolution of the zona pellucida by uterine or embryonic enzymes. It is a prerequisite for implantation.)

Table 3. Effect of restraint stress (08:30-13:30 h Days $1-6$ of pregnancy) on reproductive characteristics of mice on Day 7 of pregnancy

\begin{tabular}{lcc}
\hline & \multicolumn{2}{c}{ Treatment } \\
\cline { 2 - 3 } Characteristic & Control & Stress \\
\hline $\begin{array}{l}\text { Animals with } \\
\text { implantation sites }\end{array}$ & $9 / 12$ & $6 / 12$ \\
$\begin{array}{l}\text { Anmals with abnormal } \\
\quad \text { corpora lutea }\end{array}$ & $1 / 12^{\mathrm{a}}$ & $7 / 12^{\mathrm{b}}$ \\
$\begin{array}{l}\text { Implantation sites } \\
\text { per animal }\end{array}$ & $6 \cdot 7 \pm 1 \cdot 2^{\mathrm{e}}$ & $4 \cdot 6 \pm 1 \cdot 4^{\mathrm{f}}$ \\
$\begin{array}{l}\text { Corpora lutea per animal } \\
\quad \text { Normal } \\
\quad \text { Abnormal }\end{array}$ & $9 \cdot 0 \pm 0 \cdot 6^{\mathrm{c}}$ & $3 \cdot 7 \pm 1 \cdot 6^{\mathrm{d}}$ \\
$\begin{array}{l}\text { Serum progesterone } \\
(\mathrm{ng} / \mathrm{ml}) \dagger\end{array}$ & $0 \cdot 4 \pm 0 \cdot 4^{\mathrm{c}}$ & $5 \cdot 2 \pm 1 \cdot 3^{\mathrm{d}}$ \\
\hline
\end{tabular}

Values are mean \pm s.e.m.

+ Progesterone values for 6 control and 6 stressed mice.

a.b Values with different superscripts are different, $P<0.01$.

c.d Means with different superscripts are different, $P<0.05$.

e.f Means with different superscripts are different, $P<0 \cdot 10$.

Control mice had more normal CL $(P<0.05)$ and fewer abnormal CL $(P<0.05)$ than did stressed mice and the percentage of control mice with one or more abnormal CL was less than in stressed mice $(P<0 \cdot 01)$. All control mice had CL (whether or not they had implantation sites, i.e. they were pseudopregnant) but one stressed mouse had only follicles and small corpora albicantia, presumably due to a failure to maintain pseudopregnancy.

Serum progesterone concentrations in 6 of the 12 pairs were lower $(P<0.05)$ in the stressed animals than in the control animals $(13.5 \pm 2.4$ and $6.0 \pm 2.5 \mathrm{ng} / \mathrm{ml}$, mean \pm s.e.m.). These 6 control animals averaged $6.8 \pm 1.6$ fetuses, $9 \cdot 3 \pm 0.6$ normal CL and 0 abnormal CL. One control mouse had no fetuses but 9 normal CL (i.e. pseudopregnant, serum progesterone $=6 \cdot 3 \mathrm{ng} / \mathrm{ml}$ ). Three of the 6 stressed mice had normal CL (average 11.3 \pm 0.7 ) and a mean of $8.7 \pm 0.9$ fetuses. Serum progesterone for these 3 mice was $9.5 \pm 4.3 \mathrm{ng} / \mathrm{ml}$. The remaining 3 stressed mice had only abnormal CL (mean of $9 \cdot 0 \pm 0 \cdot 6$ ). Two of these mice had no fetuses (although one had degenerating embryos in the oviducts) and one mouse had 9 resorbing fetuses in the uterus. Serum progesterone was $<2.5 \mathrm{ng} / \mathrm{ml}$ (undetectable) in these 3 mice. 


\section{Experiment 3}

Embryos were present in the oviducts and uteri of $90 \%$ of control and stressed mice, but the distribution of the embryos between these two sites tended to be different in the stressed mice (Table 4). Of stressed mice, $50 \%$ had some embryos in the oviducts on Day 4 as compared with $10 \%$ of control mice $(P<0 \cdot 10)$. Mean number of embryos in the uterus did not vary between control and stressed mice but mean number of embryos in the oviducts was different $(P<0.05)$. A greater percentage of the embryos in the control mice were blastocysts than in the stressed mice $(P<0.05)$. Abnormal CL were present in $60 \%$ of stressed and $30 \%$ of control mice $(P>0 \cdot 10)$. The mean number of normal CL was higher $(P<0.05)$ in control mice and the mean number of abnormal $C L$ was higher $(P<0.05)$ in stressed mice. Of the 5 stressed animals with embryos in the oviducts, 3 had one or more abnormal CL in the ovaries. The one control mouse with embryos (one) in the oviducts had only normal CL.

Table 4. Effect of restraint stress $(08: 30-13: 30 \mathrm{~h}$ on Days 1-3 of pregnancy) on reproductive characteristics of mice on Day 4 of pregnancy

\begin{tabular}{lcc}
\hline & \multicolumn{2}{c}{ Treatment } \\
\cline { 2 - 3 } Characteristics & Control & Stress \\
\hline $\begin{array}{l}\text { Animals with embryos } \\
\text { Animals with embryos } \\
\text { in oviducts }\end{array}$ & $9 / 10$ & $9 / 10$ \\
$\begin{array}{l}\text { \% Blastocysts } \\
\text { Animals with abnormal }\end{array}$ & $1 / 10^{\mathrm{a}}$ & $5 / 10^{\mathrm{b}}$ \\
$\quad$ corpora lutea & $59 / 71(83)^{\mathrm{c}}$ & $51 / 78(65)^{\mathrm{d}}$ \\
$\begin{array}{l}\text { Embryos/animal in: } \\
\quad \text { Uterus }\end{array}$ & $3 / 10$ & $6 / 10$ \\
$\quad \begin{array}{l}\text { Oviducts } \\
\text { Corpora lutea per animal: } \\
\quad \text { Normal } \\
\text { Abnormal }\end{array}$ & $7 \cdot 0 \pm 1 \cdot 1$ & $5 \cdot 8 \pm 1 \cdot 3$ \\
\hline
\end{tabular}

Values are mean \pm s.e.m.

a,b Values with different superscripts are different, $P<0 \cdot 10$.

c,d Values/means with different superscripts are different, $P<0.05$.

\section{Discussion}

Restraint stress on Days 1-3, 4-6 or 1-6 of pregnancy reduced the pregnancy rate and average litter size of mice as compared to controls (Table 1). Stress for $5 \mathrm{~h}$ on Days 1-3 or 4-6 was equally effective in reducing average litter size but stress for 6 days resulted in a further decrease in this measure. Indeed, the effects of stress for each 3-day interval appeared to be additive. Euker \& Riegle (1973) found that a 2 -h restraint on Days 1 through 5 of pregnancy in rats reduced average litter size at birth from about 8.5 to 4 young (extrapolated from graphs). The average litter size at birth after 5 days of restraint in rats (47\% of controls) was therefore intermediate to the average litter size in mice after 3 or 6 days of stress ( 74 and $40 \%$, respectively). The main reproductive events occurring during the first 3 days of pregnancy are embryo transport through the oviduct and cleavage, while 
blastocyst expansion, hatching and implantation occur over the next 3-day interval. It therefore appears that these events may be equally susceptible to the deleterious effects of restraint stress. (Fertilization occurred before the first application of the stress.) Restraint stress could be having diverse effects on all these events through mediated changes in corpus luteum progesterone production, the luteotrophic agent, prolactin, direct or indirect effects of ACTH, glucocorticoids, and catecholamines or increased activity of adrenergic nerve endings in the ovary, oviducts or uteri (Euker \& Riegle, 1973).

Restraint stress in the morning (a.m.) caused a greater decrease in average litter size than did stress in the afternoon (p.m.). This differential effect of time of stress suggests that a hormone (or hormones) showing a circadian rhythm in blood levels may be involved. Prolactin and corticosterone (or ACTH) are the most likely candidates. Mated mice show a pattern of prolactin secretion composed of daily surges appearing with semicircadian rhythmicity from Days 1 to 9 of pregnancy (Mednick, Barkley \& Geschwind, 1980). A diurnal surge (15:00-21:00 h) peaks about 18:00 h and a nocturnal surge $(24: 00-09: 00 \mathrm{~h})$ peaks between $24: 00$ and $06: 00 \mathrm{~h}$. The time of restraint stress in this study was selected to correspond with either the trough in serum prolactin concentrations $(08: 00-13: 30 \mathrm{~h})$ or the beginning and the peak of the diurnal surge $(13: 30-18: 30 \mathrm{~h})$. If restraint stress is affecting reproductive success through changes in serum prolactin concentrations, it is not clear whether hypo- or hyperprolactinaemia is the likely cause. Both inadequate (Bartke, 1973; Mednick \& Barkley, 1979; Mednick et al., 1980) and excessive prolactin secretion (Kittinger et al., 1980) have been associated with pregnancy failure. Restraint stress in rats seems to increase serum prolactin concentrations if pretreatment values are low but reductions in serum prolactin concentrations have been found if stress occurs during prolactin surges (Riegle \& Meites, 1976). Thus, the a.m. stress in this study would be expected to cause hyperprolactinaemia while the p.m. stress might cause hypoprolactinaemia (relative to normal blood levels at these times).

Stress-induced changes in ACTH and corticosteroids cannot be overlooked when discussing the differential effect of time of day of restraint on pregnancy. Restraint is an effective means of activating the hypothalamic-pituitary-adrenal axis (Riegle, 1973) and the specific stressor used in this study (restraint in a wire-mesh cone) has been shown to raise plasma corticosterone concentrations (and presumably ACTH) 3-fold over those in control mice (Blecha et al., 1982). Both ACTH and adrenal corticoids have been shown to affect pregnant laboratory rodents (Velardo, 1957; Kittinger et al., 1980). Since both hormones show a circadian rhythm in mice and rats (Guillemin, Dear \& Liebelt, 1959; Halberg, Peterson \& Silber, 1959; Retienne, Zimmermann, Schindler \& Lipscomb, 1968) with blood levels peaking before the onset of darkness, it would not be unexpected to see responses to stress varying at different times of the day. Euker \& Riegle (1973) subjected animals to $2 \mathrm{~h}$ of restraint stress between $08: 30$ and $11: 30 \mathrm{~h}$ on Days 1-5 of pregnancy and the average litter size of the stressed rats $(47 \%$ of controls) is closer to the average litter size of the mice in this study that were stressed a.m. than those stressed p.m. (54 vs 73\% for controls, respectively). In separate experiments, SW females showed responses to restraint stress similar to those shown by the threeway cross females used in Exps 1-3, with a.m. stress having a greater effect than p.m. stress (data not shown). The stress effects found in this study are therefore not unique to one strain of mouse.

The effect of restraint stress on pregnancy was all-or-none. Animals that were pregnant on Day 18 of pregnancy after 3 or 6 days of stress had litters of normal size (Table 2). Thus, lower average litter size in stressed mice was accounted for by a lower pregnancy rate (Table 1). Stressed animals that were pregnant on Day 18 actually tended $(P=0 \cdot 16)$ to have larger litters than their respective controls although Day 1 body weights were similar. Whether or not a control mouse was pregnant at Day 18 appeared to be a random event, relative to the animal's body weight at the time of mating, but stressed animals that were pregnant on Day 18 had heavier Day 1 body weights than did stressed animals that were not pregnant on Day 18. Heavier animals therefore appeared to be more resistant to the effects of restraint stress. Body weight is highly correlated with ovulation rate (Fowler \& Edwards, 1960) or litter size (Falconer, 1960; Elliot, Legates \& Ulberg, 1968; Bakker, 
Wallings \& Politiek, 1978) as found in this study. A heavier body weight and a larger number of ovulations and resultant CL might therefore provide more of a 'safety factor' allowing these animals to maintain their pregnancy when stressed, while animals of lower body weight and fewer ovulations and CL are overwhelmed by the effects of the restraint stress.

The results of Exps 2 and 3 provide information essential to understanding how the negative effects of restraint stress on pregnancy are mediated (Tables 3,4). Stress was given a.m. in these experiments because it is more effective than that given p.m. in reducing average litter size. After 6 days of restraint stress, there was no significant effect on pregnancy rate or the number of implantation sites but there was an increase in the percentage of stressed animals with abnormal CL and in the average number of abnormal CL per stressed mouse. At the same time, the average number of normal CL in these mice decreased. The gross appearance of 'normal' $C L$ is red or pink and highly vascularized. The 'abnormal' $C L$ seen in this study were as large as normal CL but usually appeared strikingly white (occasionally pale) with no apparent blood vessels on their surfaces. They differed from corpora albicantia in that the latter are also white but smaller than normal CL. Abnormal CL occurred at a low incidence in control animals. The presence of a large number of these abnormal CL in stressed mice was associated with an absence of detectable progesterone in the serum.

Stressed mice also showed incidences of failure to maintain pseudopregnancy, abnormal embryo transport (degenerate embryos in oviducts), implantation failure (unimplanted hatched blastocysts) and post-implantation losses (resorbing fetuses). None of these occurred in control mice. Abnormal embryo transport and development was evident after only 3 days of a.m. stress (on Day 4) and abnormal CL were present in increased numbers in stressed mice (Table 4), although the number of abnormal CL was less than that seen after 6 days of a.m. stress.

Based on the results of Exp. 1, we would expect only $20 \%$ of mice to be pregnant on Day 18 after 6 days of a.m. stress. In Exp. 2, 50\% of stressed animals still had implantation sites on Day 7 . Some of the fetal losses in Exp. 1 must therefore have occurred after termination of the restraint. Euker \& Riegle (1973) found that restraint stress in rats on Days 1-5 of pregnancy resulted in most pregnancy losses by Day 8 although some occurred between Days 8 and 14 .

Inadequate progesterone secretion by the $\mathrm{CL}$ could account for all the reproductive disturbances seen in the stressed mice. The proper balance of serum progesterone and oestradiol is necessary both for embryo transport and development (Roblero \& Garavagno, 1979). Progesterone is necessary for the maintenance of pregnancy and, along with an oestradiol surge, for implantation (Deanesly, 1966; McCormack \& Greenwald, 1974). As discussed previously, prolactin, ACTH and corticosteroids could all be involved in mediating these stress responses. Luteal regression in pregnant laboratory rodents is not preceded by decreases in blood flow or vascular degeneration (Bruce, Meyer \& Dharmarajan, 1984). However, the avascularity of the abnormal CL in these stressed mice and the associated decline in blood progesterone could be accounted for by vasoconstriction as a result of increased sympathetic activity in luteal blood vessels or increased blood catecholamines. Restraint stress triggers massive adrenal-medullary discharge of adrenaline and sympathetic neuronal release of noradrenaline (Kvetnansky et al., 1978). Decreased blood flow to the oviducts and uterus could also result from the rise in blood catecholamines and oviduct and uterine motility are also regulated by these compounds (Jansen, 1984). With such a diverse response to stress in early pregnancy, the individual roles of the hormones involved will be difficult to determine.

We thank Ms Sandra Davidge for technical assistance and Dr Liné Estergreen for provision of the progesterone antibody and facilities. Scientific paper no. 6912, College of Agriculture and Home Economics Research Center, Washington State University. 


\section{References}

Bakker, H., Wallings, J.H. \& Politiek, R.D. (1978) Reproduction and body weight of mice after longterm selection for large litter size. J. Anim. Sci. 46, 1572-1580.

Bartke, A. (1973) Differential requirements for prolactin during pregnancy in the mouse. Biol. Reprod. 9, 379-383.

Blecha, F., Kelley, K.W. \& Satterlee, D.G. (1982) Adrenal involvement in the expression of delayedtype hypersensitivity to SRBC and contact sensitivity to DNFB in stressed mice. Proc. Soc. exp. Biol. Med. $169,247-252$.

Brinster, R.L. (1965) Studies on the development of mouse embryos in vitro. IV. Interaction of energy sources. J. Reprod. Fert. 10, 227-240.

Bruce, N.W., Meyer, G.T. \& Dharmarajan, A.M. (1984) Rate of blood flow and growth of the corpora lutea of pregnancy and of previous cycles throughout pregnancy in the rat. $J$. Reprod. Fert. 71, 445-452.

Chang, C.F. \& Estergreen, V.L. (1983) Development of a direct enzyme immunoassay of milk progesterone and its application to pregnancy diagnosis in cows. Steroids 41, 173-195.

Christian, J.J. \& Lemunyan, C.D. (1958) Adverse effects of crowding on lactation and reproduction of mice and two generations of their progeny. Endocrinology $63,517-529$.

Deanesly, R. (1966) The endocrinology of pregnancy and fetal life. In Marshall's Physiology of Reproduction, 3rd edn, Vol. 3, pp. 891-1063. Ed. A. S. Parkes. Longmans Green, London.

Elliott, D.S., Legates, J.E. \& Ulberg, L.C. (1968) Changes in the reproductive processes of mice selected for large and small body size. J. Reprod. Fert. 17, 9-18.

Euker, J.S. \& Riegle, G.D. (1973) Effects of stress on pregnancy in the rat. $J$. Reprod. Fert. 34, 343-346.

Falconer, D.S. (1960) The genetics of litter size in mice. $J$. cell Comp. Physiol. 56, Suppl. 1, 153-167.

Fowler, R.E. \& Edwards, R.G. (1960) The fertility of mice selected for large or small body size. Genet. Res. 1, 393-407.

Guillemin, R., Dear, W.E. \& Liebelt, R.A. (1959) Nychthemeral variations in plasma free corticosteroid levels of the rat. Proc. Soc. exp. Biol. Med. 101, 394-395.

Halberg, F., Peterson, R.E. \& Silber, R.H. (1959) Phase relations of 24 -hour periodicities in blood corticosterone, mitoses in cortical adrenal parenchyma, and total body activity. Endocrinology 64, 222-230.

Herrenkohl, L.R. (1979) Prenatal stress reduces fertility and fecundity in female offspring. Science, N.Y. 206, 1097-1099.

Jansen, R.P.S. (1984) Endocrine response in the fallopian tube. Endocr. Rev. 5, 525-551.
Keeley, K. (1962) Prenatal influence on behavior of offspring of crowded mice. Science, N.Y. 135, $44-45$.

Kittinger, J.W., Gutierrez-Cernosek, R.M., Cernosek, S.F., Jr \& Pasely, J.N. (1980) Effects of adrenocorticotropin on pregnancy and prolactin in mice. Endocrinology 107, 616-621.

Kvetnansky, R., Sun, C.L., Lake, C.R., Thoa, N., Torda, T. \& Kopin, I.J. (1978) Effect of handling and forced immobilization on rat plasma levels of epinephrine, norepinephrine, and dopamine- $\beta$-hydroxylase. Endocrinology 103, 1868-1874.

McCormack, J.T. \& Greenwald, G.S. (1974) Evidence for a preimplantation rise in oestradiol-17 $\beta$ levels on Day 4 of pregnancy in the mouse. J. Reprod. Fert. 41, 297-301.

Mednick, D.L. \& Barkley, M.S. (1979) Effect of CB-154 or anti-LH on progesterone secretion and fetal viability during the first ten days of mouse gestation. Biol. Reprod. 20, Suppl. 1, 101A, Abstr.

Mednick, D.L., Barkley, M.S. \& Geschwind, I.I. (1980) Regulation of progesterone secretion by $\mathrm{LH}$ and prolactin during the first half of pregnancy in the mouse. J. Reprod. Fert. 60, 201-207.

Retienne, K., Zimmermann, W.I., Schindler, C.J. \& Lipscomb, H.S. (1968) A correlative study of resting endocrine rhythms in rats. Acta endocr., Copenh. 57, 615-622.

Riegle, G.D. (1973) Chronic stress effects on adrenocortical responsiveness in young and aged rats. Neuroendocrinology 11, 1-10.

Riegle, G.D. \& Meites, J. (1976) The effect of stress on serum prolactin in the female rat. Proc. Soc. exp. Biol. Med. 152, 441-448.

Roblero, L.S. \& Garavagno, A.C. (1979) Effect of oestradiol-17 $\beta$ and progesterone on oviductal transport and early development of mouse embryos. $J$. Reprod. Fert. 57, 91-95.

Surve, A.H., Bacso, I., Brinckerhof, J.H. \& Kirsch, S.J. (1976) Plasma level of progesterone in pseudopregnant rabbits actively immunized with a progesteroneprotein conjugate. Biol. Reprod. 15, 343-349.

Velardo, J.T. (1957) Action of adrenocorticotropin on pregnancy and litter size in rats. Am.J. Physiol. 191, 319-322.

Whitten, W.K. (1956) Modification of the oestrous cycle of the mouse by external stimuli associated with the male. J. Endocr. 13, 399-404.

Zondek, B. \& Tamari, I. (1967) Effects of auditory stimuli on reproduction. In The Effects of External Stimuli on Reproduction (Ciba Fdn Study Group No. 26), pp. 4-19. Eds G. E. W. Wolstenholme \& M. O'Connor. Little, Brown and Company, Boston.

Received 3 January 1986 